\title{
PHYSICIAN ADVERTISING: THE FIRST AMENDMENT AND THE SHERMAN ACT
}

\author{
William C. Canby, Jr.* and ERnest GellhorN**
}

In Bates v. State Bar of Arizona, ${ }^{1}$ the Supreme Court held that a state's prohibition of advertising by attorneys was unconstitutional as applied to a newspaper advertisement setting forth fees for certain routine legal services. Bates is necessarily the foundation upon which one must base any judgment regarding the legality of restraints upon physicians' advertising.

Restraints on advertising potentially violate two distinct legal commands - the first amendment and the Sherman Act ${ }^{2}$ - both of which were considered by the Bates Court. The plaintiff in Bates ultimately prevailed on the basis of the first amendment. The Sherman Act claim was rejected on the ground that since the Sherman Act was not intended to reach the direct action of a state, ${ }^{3}$ the Arizona Supreme Court's actions in adopting and enforcing the advertising ban ${ }^{4}$ were not within the scope of the Act. This Article will first examine the Bates decision and then analyze the first amendment and Sherman Act implications for restraints on advertising by physicians.

\section{BATES: SuCCess of the First Amendment Challenge}

The first amendment challenge in Bates rested heavily on a Supreme Court decision of the previous term, Virginia State Board of Pharmacy v. Virginia Citizens Consumer Council, Inc. ${ }^{5}$ The Court in

- Professor of Law, Arizona State University. Professor Canby was counsel for appellants Bates and O'Steen in Bates v. State Bar of Arizona.

** Dean and Professor of Law, University of Washington.

l. 433 U.S. 350 (1977).

2. 15 U.S.C. $\$ \S 1-7$ (1976).

3. Parker v. Brown, 317 U.S. 341, 351 (1943). See generally Comment, The State Action Exemption in Antitrust: From Parker v. Brown to Cantor v. Detroit Edison Co., 1977 DUKE L.J. 871.

4. The State Bar of Arizona is under the direction and control of the Supreme Court of Arizona. ARIz. SUP. CT. R. 17(a). Because all persons licensed to practice law in Arizona also must be members of the state bar, ARIz. REv. STAT. § 32-261 (1976), all Arizona attorneys are subject to its rules.

5. 425 U.S. 748 (1976). 
that case extended its growing protection of commercial speech ${ }^{6}$ to a simple advertised offer to sell "the X prescription drug at the Y Price." The Court rejected arguments that the state's ban on such drug price advertising was essential to preserve professionalism and high quality of service by pharmacists. ${ }^{8}$ It noted that commercial advertisements contain information important to individual consumer decision making, which is in turn important to the allocation of resources in a free market economy. 9

The question in Bates was whether the Court would adhere to its recently announced protection of commercial speech in the case of the more traditional profession of law. It did, but by a bare majority. Two additional Justices would have permitted some advertising by attorneys, but not that of fees for specific services. ${ }^{10}$ An analysis of the Court's reasoning is important to an understanding of Bates' potential application to physicians.

The majority opinion in Bates reiterated the reasoning of Virginia State Board of Pharmacy and its emphasis on the value of advertising to the individual and the economy. ${ }^{11}$ The Court then systematically rejected several proffered justifications for the advertising prohibition. It stated that advertising would not degrade the profession in either the attorneys' or the public's eyes; the public knows that attorneys make money at their calling. ${ }^{12}$ Nor would it lead to shoddy services; the attorney who is inclined to cut quality to increase profits will do so whether or not he advertises. ${ }^{13}$ The Court also found that advertising should not be prohibited even if it resulted in increased litigation be-

6. In stating that "the notion of unprotected 'commercial speech' [has] all but passed from the scene," 425 U.S. at 759, the Court in Virginia State Bd. of Pharmacy completed a dramatic first amendment development. Valentine v. Chrestensen, 316 U.S. 52 (1942), had long stood for the proposition that purely commercial speech was not protected by the first amendment. Id. at 54-55. The Valentine doctrine, however, was often criticized, even by members of the Court. See Bigelow v. Virginia, 421 U.S. 809, 820 n.6 (1975). The first hint of the erosion of the doctrine appeared in Pittsburgh Press Co. v. Pittsburgh Comm'n on Human Relations, 413 U.S. 376 (1973), in which a newspaper unsuccessfully attempted to assert in the face of a restrictive city ordinance a first amendment interest in its classified ads. Two years later in Bigelow v. Virginia, 421 U.S. 809 (1975), the Court reversed a criminal conviction for violating a statute prohibiting the circulation of any publication promoting abortion services. In affording first amendment protection to this commercial speech, the Court stated that the "relationship of speech to the marketplace of products . . does not make it valueless in the marketplace of ideas." 421 U.S. at 826.

7. 425 U.S. at 761.

8. Id. at 768-69.

9. Id. at $763-65$.

10. 433 U.S. at 389 (Powell, J., concurring, joined by Stewart, J.).

11. Id. at 374-75.

12. Id. at $368-69$.

13. Id. at 378 . 
cause use of the courts is not an evil. ${ }^{14}$ Nor was there any convincing evidence that advertising would have adverse economic effects, either by increasing the costs to the consumer or by providing a barrier to entering attorneys. ${ }^{15}$ On the contrary, the Court viewed advertising as more likely to bring fees down by competition and by providing a way for a new attorney to attract clients. The Court was also unconvinced that abuses of advertising would create an insupportable burden of enforcement for the bar. ${ }^{16}$

To the medical profession, perhaps the most significant part of the Court's opinion in Bates was its rejection of the contention that advertising of attorneys' services is inherently misleading. The argument was founded upon several propositions: that legal services are so individualized that they do not permit comparison by way of advertisements; that the consumer is unable to determine in advance what services he needs; and that advertisements would highlight irrelevant factors and would fail to show the relevant factor of skill. To the first point, the Court answered that those services for which set fees would be advertised were relatively standardized and that the bar association's own prepaid services plan established set fees for such services. ${ }^{17}$ Although there would be variations, there would be no deception so long as the described service was performed for the advertised fee. To the second proposition, the Court stated:

It is unlikely that many people go to an attorney merely to ascertain if they have a clean bill of legal health. Rather, attorneys are likely to be employed to perform specific tasks. Although the client may not know the detail involved in performing the task, he no doubt is able to identify the service he desires at the level of generality to which advertising lends itself. ${ }^{18}$

In response to the third proposition, the Court acknowledged that advertising does not provide all the information necessary to the selection of an attorney, but countered that some information is better than none. ${ }^{19}$

14. Id. at $375-77$.

15. Id. at 377-78.

16. Id. at 379.

17. Id. at $\mathbf{3 7 2 - 7 3 .}$

18. Id. at 374.

19. Id. The Court went on to hold that it would not invalidate regulation of professional advertising on grounds of overbreadth; that is, it would not strike down the rule simply because it might in some potential applications violate the first amendment. Id. at 379-81. Any successful attack on the rule would have to be carried out by a litigant whose own advertisement was entitled to first amendment protection. The court held that the Bates advertisement was protected, and that it was not deceptive in describing the practice as a "legal clinic," in stating that its fees were "very reasonable," or in failing to state that a lawyer's services were not essential to obtain a change of name, which was one of the advertised services. Id. at 381-82. 
The Court closed its opinion as it had opened it, with a statement of the limits of its decision. The case did not deal with advertising the quality of services, which "may be so likely to be misleading as to warrant restriction." 20 Nor did it deal with in-person solicitation, which might be subject to similar objections. It is clear, said the Court, that false and deceptive advertising may be prohibited, as may the advertising of transactions that are themselves illegal. ${ }^{21}$ Time, place and manner restrictions may be imposed, and "the special problems of advertising on the electronic broadcast media will warrant special consideration." 22 All of these disclaimers, then, are likely to represent a schedule of future litigation as the full import of the Bates decision develops. The only certain fact is that the Bates advertisement of specific legal services at stated fees was protected by the first amendment.

\section{Application of the First Amendment to Physician ADVERTISING}

\section{A. Restraints Upon Physician Advertising.}

At its first national convention in 1847, the American Medical Association (AMA) promulgated a code of professional ethics, which evolved into the Principles of Medical Ethics. ${ }^{23}$ The Principles were revised into their present form in 1955. Section 5 provides in pertinent part: "A physician may choose whom he will serve . . . . He should not solicit patients." This prohibition against solicitation has for many years been interpreted to forbid virtually all public advertising by physicians. $^{24}$

The Principles of the AMA have routinely been adopted by state and local medical societies throughout the country. In addition, the medical licensure laws or regulations of over two-thirds of the states restrict or prohibit solicitation or advertising. ${ }^{25}$ As a result, the ethical restraint against advertising by individual physicians has for all practical purposes been total.

Actual enforcement of the ban has been left almost entirely to state and local medical societies; state licensing agencies have generally not

20. Id. at 383-84.

21. Id.

22. Id. at 384.

23. Jonsen \& Hellegers, Conceptual Foundations for an Ethics of Medical Care, in ETHICs of Health CARE 5 (L. Tancredi ed. 1974).

24. See Complaint of the Federal Trade Commission, AMA, FTC Dkt. No. 9064, [1973-76 Transfer Binder] TRADE REG. REP (CCH) \21,068 (1975).

25. Brief for the AMA as Amicus Curiae, Appendix A at 11, Bates v. State Bar of Ariz., 433 U.S. 350 (1977). 
exercised their power to revoke the licenses of advertising physicians. Since the medical societies are organized as nongovernmental bodies, their ultimate sanction in enforcing codes of ethics is expulsion from the society. For the physician, that is a severe penalty. Expulsion from a local medical society may result in the loss of hospital privileges which are virtually essential to the maintenance of the physician's practice. Moreover, it will usually dry up referrals, an important source of patients. Expulsion may also lead to the denial of a specialty certification, and to the loss or greatly increased cost of medical malpractice insurance. ${ }^{26}$ Policing of the advertising restriction, therefore, has been very effective.

In 1976, with an eye toward the trend of litigation, the Judicial Council of the AMA reinterpreted the Principles to permit a limited degree of advertising. Its statement included the following:

Advertising-The Principles do not proscribe advertising; they proscribe the solicitation of patients. Advertising means the action of making information or intention known to the public. The public is entitled to know the names of physicians, the type of their practices, the location of their offices, their office hours, and other useful information that will enable people to make a more informed choice of physician.

The physician may furnish this information through the accepted local media of advertising or communication . . . . 27

The statement further provided that the physician may supply biographical information to reputable directories and may include "his charge for a standard office visit or his fee or range of fees for specific types of services, provided disclosure is made of the variable and other pertinent factors affecting the amount of the fee specified."28 False and misleading advertising, puffery, testimonials and self-laudatory advertising are still prohibited. ${ }^{29}$

Despite this considerable liberalization by the AMA, restraints upon advertising today remain as total as ever, because neither the state and local societies nor the state legislatures and licensing bodies have adopted the AMA position. Moreover, it is not at all clear that they will do so voluntarily. Consequently, the issue of the validity of restraints on physician advertising is still very much alive.

26. A. Nichols, The Pricing of Physician and Lawyer Services 57 (Univ. Microfilms Int'l 1975).

27. Statement of the Judicial Council Re: Advertising and Solicitation, 235 J.A.M.A. 2328, 2328 (1976).

28. $I d$.

29. Id. 
[Vol. 1978:543

\section{B. State Action.}

In order to determine the extent to which the first amendment applies to physician advertising, it is first necessary to consider whether the system of regulation involves sufficient state action to trigger constitutional scrutiny. Only if such governmental action is found can the substantive questions relating to the protection of advertising as commercial speech be reached. ${ }^{30}$

State and local medical societies might be expected to argue that their enforcement of their own ethical standards is entirely a private matter not subject to constitutional scrutiny. Some courts have lent support to that view. ${ }^{31}$ In enforcing the advertising ban, however, the state and local societies seem certain to be sufficiently infected with state action to permit application of the first amendment. The state licensing bodies and legislatures that have passed regulations or laws prohibiting advertising are of course acting as the state, and the first amendment applies to them directly. But these statutes and regulations also provide the type of governmental encouragement to the medical societies in enforcing their own bans that might lead a court to conclude that such enforcement by the societies cannot be regarded as wholly private. The Supreme Court has found state action under similar circumstances in cases of racial discrimination, ${ }^{32}$ and it is possible that the Court would also do so in cases involving the first amendment, despite the likelihood that a more stringent test of state action would be applied..$^{33}$

30. The requirement that "state action" be present before the constitutional safeguard is triggered does not generally pose a problem when the state or its authorized agent is the primary "actor"; rather, the doctrinal difficulty arises when nominally private parties perform "public functions" or when the state subsidizes, regulates or cooperates with private parties whose actions violate constitutional rights. See Jackson v. Metropolitan Edison Co., 419 U.S. 345 (1974) (licensing and extensive regulation of public utility which has received grant of monopoly from the state does not make utility state agent); Burton v. Wilmington Parking Auth., 365 U.S. 715 (1961) (leasing of space in a publicly owned parking ramp to restaurant maintaining racial segregation makes restaurant's actions equivalent to state action; crucial fact is that the state and the private party were in a "symbiotic relationship"); Shelley v. Kraemer, 334 U.S. 1 (1948) (state action present when state court grants injunctive relief to private parties seeking to enforce racially restrictive covenants).

31. E.g., Schooler v. Tarrant County Medical Soc'y, 457 S.W.2d 644 (Tex. Civ. App. 1970); cf. Levin v. Sinai Hosp., 186 Md. 174, 46 A.2d 298 (1946) (private hospital has right to exclude any physician from practice within the discretion of the management).

32. Reitman v. Mulkey, 387 U.S. 369 (1967); cf. Adickes v. S.H. Kress \& Co., 398 U.S. 144 (1970) (repeated actions of state officials may be state action if the custom has the force of law); Lombard v. Louisiana, 373 U.S. 267 (1963) (statements by city officials indicating they would not tolerate integration found to constitute state action in the absence of statutory command); Peterson v. City of Greenville, 373 U.S. 244 (1963) (discriminatory act of private party constitutes state action when city ordinance requires the result).

33. The Court has recently taken a more restrictive stance regarding state action in cases not 
There are other connections as well between the societies and government which the courts might rely upon to buttress a finding of state action. The societies frequently participate officially in the selection of members of the state licensing boards. ${ }^{34}$ The hospitals from which an expelled member would be excluded are likely to be partially or entirely funded by government. ${ }^{35}$ Informal interdependence between state and local health departments and the societies may exist in varying degrees. While any of these connections in itself might not suffice, the cumulative effect is such that the societies will almost certainly have to contend with the application of the first amendment to their restraints upon advertising. ${ }^{36}$

\section{Physician Advertising as Protected Speech.}

Surely the outcome of the Bates case creates a working presumption that the first amendment will invalidate any total ban on professional advertising. Still, it is appropriate to inquire whether the reasoning behind Bates applies in full force to physician advertising and, if not, what other support might exist for an application of the first amendment.

One of the justifications for the Bates ruling arose from a combination of consumer ignorance and underutilization of legal services. A survey conducted by the American Bar Association (ABA) and the American Bar Foundation indicated that one-third of all Americans never consulted a lawyer in their lives, and another third did so once. ${ }^{37}$

involving racial discrimination. The strongest indication of this development is Jackson v. Metropolitan Edison Co., 419 U.S. 345 (1974), in which the Court refrained from finding state action on the basis of the licensing and pervasive governmental regulation of a utility company. Justice Rehnquist set forth the applicable test for a finding of state action: "[T] he inquiry must be whether there is a sufficiently close nexus between the State and the challenged action of the regulated entity so that the action of the latter may be fairly treated as that of the State itself." Id. at 351. See also Lloyd Corp. v. Tanner, 407 U.S. 551 (1972).

34. A. Nichols, supra note 26 , at $49-50$.

35. A number of cases have dealt with the question whether the receipt of funds under the Hill-Burton Act (Hospital Survey and Construction Act), 42 U.S.C. $\$ \$ 291$ to 2910-1 (1970), makes the actions of a private hospital state action. Under current law, it appears that the mere receipt of Hill-Burton funds is an insufficient basis for state action, at least in the absence of racial discrimination. Compare Ascherman v. Presbyterian Hosp., 507 F.2d 1103 (9th Cir. 1974) (allegation that hospital violated due process clause by arbitrary denial of staff privileges) and Doe v. Bellin Mem. Hosp., 479 F.2d 756 (7th Cir. 1973) (right of privacy not violated by refusal of hospital to perform abortions) with Simkins v. Cone Mem. Hosp., 323 F.2d 959 (4th Cir. 1963), cert. denied, 376 U.S. 938 (1964) (receipt of Hill-Burton funds makes the discriminatory denial of staff privileges to a Negro physician state action).

36. See Burton v. Wilmington Parking Auth., 365 U.S. 715 (1961); Hawkins v. North Carolina Dental Soc'y, 355 F.2d 718 (4th Cir. 1966).

37. See B. Curran \& F. Spalding, The Legal Needs of the Public 85-86 (Am. Bar Foundation Prelim. Report 1974). 
Millions of people did not know a lawyer, did not know how to find one and tended to overestimate what lawyers would charge for their services. ${ }^{38}$ Lack of information was consequently an integral part of a failure of the delivery system for legal services. This failure of delivery had its own independent constitutional implications, for the Court had recognized a first amendment and due process right to legal services. ${ }^{39}$

Suppression of physician advertising, on the other hand, might not be seen as intimately connected with a failure in the delivery system for medical services. There is a much higher utilization rate of medical services than of legal services; the average American receives some sort of medical attention several times a year. ${ }^{40}$ And while medical services are clearly important and sometimes vital to the individual, they do not of themselves enjoy the status of a constitutional right, except for abortion and birth control services. ${ }^{41}$ The goal of increasing the use of physicians' services consequently does not loom as large as the parallel consideration in the Bates case. Indeed, an increase in demand for medical services might well be viewed in part as a social and economic problem.

Nonetheless, few would contend that the delivery system for medical services is perfect, or that an increase in the flow of information might not aid persons who need medical services in finding and choosing a physician. As the AMA has now recognized, advertising can convey information useful to the consumer. ${ }^{42}$ At the most basic level, information regarding the location of the physician's office, his hours, language ability and his specialty, if any, are all obviously helpful to an individual searching for a physician.

The advertising of specific fees is especially important. Bates, after all, was a case about the advertising of fees, and in this regard several points need to be made. First, fee advertising presented the most distasteful case for a Supreme Court raised in the lawyers' traditions. It seems clear, for instance, that Justices Powell and Stewart would have supported the protection of other kinds of advertising; ${ }^{43}$ it was the ele-

38. See Bates, 433 U.S. at 370 n.22; AM. BAR NEws, Mar. 1976, at 8.

39. United Transp. Union v. State Bar of Mich., 401 U.S. 576 (1971); UMW v. Illinois State Bar Ass'n, 389 U.S. 217 (1967); Brotherhood of R.R. Trainmen v. Virginia State Bar, 377 U.S. 1 (1964); NAACP v. Button, 371 U.S. 415 (1963).

40. A. Nichols, supra note 26, at 3 (citing U.S. Dept. of Health, Education and Welfare, Public Health Service, Health Services and Mental Health Administration, Physician Visits: Volume and Interval Since Last Visit, United States-1969 in Vital and HEALth Statistics 1, 3 (Series 10, No. 75)).

41. See Doe v. Bolton, 410 U.S. 179 (1973); Roe v. Wade, 410 U.S. 113 (1973); Griswold v. Connecticut, 381 U.S. 479 (1965).

42. See text accompanying note 27 supra.

43. 433 U.S. at $391-95$ (Powell, J., concurring, joined by Stewart, J.). 
ment of price that most concerned them and turned Bates into a 5-4 decision. Yet the first amendment policy arguments are strongest in the case of price advertising. As the majority opinion recognized, price is often the most significant single fact for the consumer. ${ }^{44}$ More importantly, informed price decisions by individual consumers are the means of efficiently allocating resources in a free market economy. Price advertising, as the economic testimony in Bates clearly indicated, ${ }^{45}$ is procompetitive and tends to bring price levels down. All of these factors were relied upon by the majority to justify applying the first amendment to commercial speech by attorneys. The same elements, of course, may well be even more significant for antitrust purposes.

The root of these economic arguments, however, is individual consumer choice, and in medicine this choice is not as large a factor as it is in law. While initial choice of a physician is usually made by the consumer, most of the economically important choices thereafter are made by the physician. This includes choice of drugs, the hospital to be used and the duration of its use, other physicians to be consulted, the tests to be conducted and, of course, the treatment to be given. ${ }^{46}$ The patient's direct interest in these choices is further diminished by the fact that about two-thirds of all personal health care expenditures are made by third parties on behalf of the consumer patients ${ }^{47}$ Of these payments, about sixty percent are made by federal, state or local government; the remainder are made by private insurers. ${ }^{48}$ The economic incentive that normally impels the consumer is accordingly attenuated in the case of medical services.

These differences in the consumer role from that prevailing in the field of legal services might tempt one to conclude that the first amendment analysis of Bates is not applicable to physician advertising. Indeed, if patient choice of physicians did not exist at all, and if this were thought to be a satisfactory condition, then such a conclusion might well follow. The Monopolies Commission in England determined that solicitors should be permitted to advertise $e^{49}$ but that there was no need to permit barristers to do so because clients never directly employed barristers; they were employed only by solicitors who, unlike the pub-

44. Id. at 396.

45. Brief for the AMA, supra note 25, Joint Appendix 187-88.

46. Schuck, A Consumer's View of the Health Care System, in Ethics of Health CARE 11012 (L. Tancredi ed. 1974).

47. Id. 103-04.

48. $I d$.

49. Monopolies and Mergers Commission, Services of Solicitors in England AND Wales: A Report on tHe Supply of SERvices of Solicitors in ENGLAND aNd Wales IN RELATION to RESTRICTIONS ON ADVERTISING (1976). 
lic, were fully informed so as to permit them to make choices among barristers. ${ }^{50}$ But patients are not wholly excluded from the choice of physicians in the United States; the initial choice is most commonly theirs. Furthermore, there is still a considerable portion of the populace that is not insured. ${ }^{51}$ There is reason to expect that these consumers will have substantial impact at the margin as they exercise their choices and seek lower-cost services. The systematic competitive effect of advertising could thus have a significant effect on the medical profession.

In addition, the dominance of physicians in exercising the important economic choices for patients is not a particularly desirable condition. The physician may have conflicting economic interests in selecting procedures, and his lack of incentive to economize doubtless contributes to the high rate of inflation in the field of health care. But, as Peter Schuck has pointed out, this dominance of the physician cannot effectively be modified if the patient is left in ignorance. ${ }^{52}$ In other words, the situation is not likely to be greatly ameliorated in the absence of advertising to inform the consumer's choice.

The Supreme Court has supplied some guidance for the protection of commercial speech in the field of medical services. In Bigelow v. Virginia $^{53}$ the Court held that an advertisement for an abortion referral service was protected by the first amendment because it conveyed information of interest to members of the public - both those who needed the services and those who might have a more general interest in the subject matter. It is true that the interest of the public was enhanced by the fact that the service offered was one which itself had acquired independent constitutional protection, ${ }^{54}$ but the Court nevertheless noted its agreement with the proposition that "this is 'a First Amendment case' and 'not an abortion case." "5s The decision certainly buttresses the view that sufficient public interest underlies medical advertising to bring it within constitutional protection. Restraints upon such advertising will therefore have to be justified by some first amendment test appropriate to commercial speech.

One highly interesting facet of the commercial speech decisions is that they have largely avoided articulating a standard of review. Under traditional first amendment doctrine, an exercise of the police power is

50. Monopolies and Mergers Commission, Barristers' Services: A Report on the SUPPLY OF BARRISTERS' SERVICES IN RELATION TO RESTRICTIONS ON ADVERTISINO 22-24 (1976).

51. Health Insurance Institute, Source Book OF Health INSURANCE Data 1975-76 5, 21-23 (17th ed. 1976).

52. Schuck, supra note 46.

53. 421 U.S. 809 (1975).

54. See Doe v. Bolton, 410 U.S. 179 (1973); Roe v. Wade, 410 U.S. 113 (1973).

55. 421 U.S. at 815 n.5. 
permitted to infringe speech only where necessary to serve a compelling governmental interest. ${ }^{56}$ Included in the concept of "necessary" is the lack of any less drastic means of accomplishing the legitimate governmental objective. ${ }^{57}$ But neither in Bigelow nor in Virginia State Board of Pharmacy did the Supreme Court specifically embrace this or, indeed, any other standard of review. It simply engaged in a weighing process between the public interest supporting advertising and the proffered interests in suppressing it.

The Bates decision adds little doctrinal enlightenment. It does seem clear from the actual disposition of Bates, however, that a highly important governmental interest is required to justify a restraint on advertising. This may well not amount to the traditional "compelling state interest," 58 but it is certainly a far more stringent requirement than a mere rational basis for the restraint. In rejecting the arguments advanced by the bar association for the suppression of advertising, the Court did not characterize any of them as irrational; it simply disagreed with the force of the arguments and stated that none of them rose "to the level of an acceptable reason for the suppression of all advertising by attorneys." "59 The Bates opinion is most instructive, however, in analyzing the specific advertisement in question and finding it to be protected. The Court believed that the public would readily understand the meaning of "legal clinic," and it rejected the argument that it was deceptive for the advertisement not to state that an attorney was unnecessary for a name change. ${ }^{60}$ With regard to the latter point, the Court stated:

The record does not unambiguously reveal some of the relevant facts in determining whether the nondisclosure is misleading, such as how complicated the procedure is and whether the State provides assistance for laymen ....

We conclude that it has not been demonstrated that the advertisement at issue could be suppressed. ${ }^{61}$

This formulation from Bates suggests two points. First, a mere tendency or possibility of harm is not sufficient to permit suppression; the harm must be demonstrated. Second, the burden is on the regulatory authority to make the required showing.

56. Dunn v. Blumstein, 405 U.S. 330, 342-43 (1972); NAACP v. Button, 371 U.S. 415,438 (1963) ("The decisions of this Court have consistently held that only a compelling state interest . . . can justify limiting First Amendment freedoms"). (1960).

57. Shelton v. Tucker, 364 U.S. 479, 488-90 (1960); Talley v. California, 362 U.S. 60, 62-64

58. See generally NAACP v. Button, 371 U.S. 415, 438-39 (1963).

59. 433 U.S. at 379.

60. Id. at 381 .

61. Id. at 382 . 
The Supreme Court's latest pronouncement on commercial speech may weaken somewhat these conclusions from Bates. In Ohralick $v$. Ohio State Bar Association, ${ }^{62}$ the Court upheld Ohio's ban on in-person commercial solicitation, holding that the practice presented sufficient likelihood of defeating a "legitimate and important state interest" 63 in avoiding fraud and overreaching so that it could be prohibited without the necessity of showing harm in each individual case. The Court also made it clear, by both word ${ }^{64}$ and deed, ${ }^{65}$ that commercial speech enjoyed a lower level of protection than political speech. There was no explicit indication, however, that the Court intended its treatment of the egregious solicitation involved in Ohralick ${ }^{66}$ to carry over to the field of pure advertising. The Ohralick decision probably cannot be read as casting doubt on the continued applicability of the Bates-type weighing process in cases of commercial advertising. When this approach is applied to the medical field, then, the question remains whether those seeking to suppress physician advertising can assert specific interests sufficient under Bates to justify a general prohibition.

\section{Asserted Justifications for Suppression of Physician Advertising.}

1. Inherent Deception. The Court in Bates adhered to its earlier pronouncements that false and deceptive advertising may be prohibited, ${ }^{67}$ but it rejected the argument that fee advertising was so inherently misleading that it should be entirely banned. ${ }^{68}$ The rejected contention perhaps has more force in the case of physicians' fee advertising. Arguably, physicians' services are typically more varied than are those of attorneys and the public is even less able to evaluate and compare the services being offered.

Interestingly enough, this argument and its refutation may be found in the Bates record, where a neurosurgeon who was chairman of the professional committee of the county medical society, testifying in defense of the prohibition, said that it would be ludicrous to advertise that craniotomies would be performed for a set fee because there were

62. 98 S. Ct. 1912 (1978).

63. Id. at 1922.

64. Id. at 1922 n.20.

65. In a contemporaneous case, In re Primus, 98 S. Ct. 1925 (1978), the Court held unconstitutional the application of a ban against solicitation to an American Civil Liberties Union attorney soliciting a civil liberties case, where no attorney would be paid for services rendered.

66. Ohralick had solicited accident victims, including one who was still hospitalized and in traction, and had concealed a tape recorder on his person to prevent one of the victims from denying her oral agreement to engage him. $98 \mathrm{~S}$. Ct. at 1915-16.

67. 433 U.S. at 383.

68. Id. at 378-79. 
over 100 types of craniotomies with infinitely complex variations. ${ }^{69} \mathrm{He}$ also testified that it would not be possible to advertise the treatment of sore throats for $\$ 26.50$ because there was infinite variety in the treatment of sore throats. ${ }^{70}$ Yet the same physician stated that it might be "possible" to advertise vasectomies for a set fee, ${ }^{71}$ and indicated that there is considerable uniformity among fees for numerous services because of the use of relative value scales which govern payment of physicians' fees by insurance companies. ${ }^{72} \mathrm{He}$ further testified that even within the individual physician's office, the bookkeeper is often given a schedule of fees for specific treatments, examinations or tests, and the physician merely checks which ones were given so that the appropriate fees may be written in by the billing bookkeeper. ${ }^{73}$ In short, several of the physician's services are so standardized that fixed fees are easily set for them. The point from the Bates opinion then becomes applicable: these standardized services are the ones that are likely to be advertised for set fees, and a ban of all fee advertising is therefore unjustified. ${ }^{74}$ The craniotomy would not be advertised for a fixed fee anyway. More importantly, even if it were, there would still be no deception if the physician performed an appropriate and needed craniotomy at the advertised fee.

It may well be true that the prospective patient is often not able to determine in advance what kinds of services he needs. But the fact that his intestinal pain may be due to gas or an infected appendix does not mean that it is useless for him to know what various physicians charge for appendectomies and which physicians perform them. The same may be said more strongly for a host of services, from abortions to electrocardiograms. Since consumers are still permitted to select their own initial physicians, some information is better than none, as the Bates Court suggested. ${ }^{75}$ The mere danger of deception in some cases does not justify a prohibition of all advertising.

2. Decline in Quality of Services. A similar argument is that the advertising of set fees would lead to a decline in the quality of services. Theoretically, the physician who has advertised a set fee would be tempted to neglect procedures that may be indicated but that would

69. Brief for the AMA, supra note 25, Joint Appendix 313-15.

70. Id. $315-26$.

71. Id. $325-26$.

72. Id. 334-36.

73. Id. $339-41$.

74. 433 U.S. at $378-79$.

75. Id. at 374 . 
cause the cost to exceed the fee. ${ }^{76}$ The answer to this argument is no different for the medical profession than for the legal one: the professional who is inclined to cut quality in order to increase profit will do so whether or not he advertises. The existence of set fees for insurance and prepaid plans indicates that such fees are workable and ought to be consistent with high-quality services. When a particular problem turns out to be especially complicated, a loss is taken on that case and made up on others. The advertised fee is set at a level that accounts for the occasional complicated case.

3. Damage to the Professional Relationship. The complaint that advertising is demeaning to the dignity of the profession hardly rises to the level of public policy if the question is simply one of the practitioner's self-image. The argument is therefore usually stated in terms of a threatened deterioration in the trust relationship between physician and patient. ${ }^{77}$ But the lawyer-client relationship is also built on trust, and the Bates Court had little difficulty concluding that this trust must be able to withstand the consumer's common knowledge that the professional is attempting to make money at his profession. ${ }^{78}$ The Court's observation that advertising does not seem to have affected the public's view of the dignity of bankers or engineers ${ }^{79}$ also seems convincing. In order to infringe a physician's freedom of speech, the first amendment requires a more definite demonstration of harm to the professional relationship than has yet been shown.

4. Costs of Advertising and Enforcement. The final points offered to support a total ban on physician advertising are practical ones which the Court also rejected in Bates. The first is that advertising will raise the cost of services to the consumer. As the Court observed, advertising is at least as likely to lower those costs by its competitive effect on prices and its aid to new attorneys seeking to enter the field. ${ }^{80} \mathrm{It}$ also may eliminate some search costs that the consumer bears in the absence of advertising. The second argument is that the profession is simply unable to assume the burden of policing deceptive or otherwise improper advertising. The Court's treatment of this problem in Bates is rather cursory; it was simply assumed that attorneys would not engage in improper advertising in any substantial numbers. ${ }^{81}$ It is unlikely that the medical profession provides any more of a demonstrable problem

76. See Brief for the AMA, supra note 25 , at 5 .

77. See, e.g., Bates, 433 U.S. at 368-72; Brief for the AMA, supra note 25, at 6-7.

78. 433 U.S. at 368-69.

79. Id. at 369-70.

80. Id. at 377-78.

81. Id. at 379 . 
in this regard. If policing ultimately becomes a substantial burden to the profession, it can always consider abandoning the field and leaving the matter to the agencies that police other false advertising. Admittedly, however, it is doubtful that either the medical profession or the Supreme Court would be content with such an alternative. In any event, problems of enforcement do not presently justify a total ban on physician advertising.

It thus seems highly improbable that the medical profession will be able to demonstrate the type of systematic and virtually inevitable harm from advertising that would justify a total prohibition. The questions that remain, then, concern the degree of regulation short of prohibition that may be permissible under the first amendment. The answers depend both upon what Bates held and what its unresolved issues portend.

\section{E. Permissible Regulation of Advertising Under the First Amendment.}

1. Overbreadth. The Supreme Court has typically permitted a litigant to attack a regulation of speech on the ground that some of its potential applications would restrict the first amendment rights of others, even though the particular expression of the litigant in question constitutionally could have been prohibited. ${ }^{82}$ This type of attack is permitted because of the danger that an overly broad regulation by its mere existence would chill the protected expression of some persons who were uncertain whether their speech was protected and who lacked the means or determination to contest the regulation directly. ${ }^{83}$ In an exhaustive and largely gratuitous discussion in Bigelow, the Court indicated that overbreadth attacks could be made against regulations of commercial speech. ${ }^{84}$ Nevertheless, the Bates Court refused to apply the overbreadth doctrine to professional advertising, on grounds that would seem equally applicable to all product and service advertising. ${ }^{85}$

The Court's reasons for rejecting overbreadth are twofold. First, the economic incentives behind commercial speech are such that it is less likely to be chilled than is pure speech. ${ }^{86}$ Second, commercial advertisers possess the facts concerning their products or services and are

82. Gooding v. Wilson, 405 U.S. 518, 520-21 (1972); e.g., Coates v. Cincinnati, 402 U.S. 611, 616 (1971).

83. Bigelow v. Virginia, 421 U.S. 809, 816 (1975). See generally Note, The First Amendment Overbreadth Doctrine, 83 HARV. L. Rev. 844 (1970).

84. 421 U.S. at 815-18.

85. 433 U.S. at $380-81$.

86. Id. at 381. 
in a better position than others to determine whether their advertising is true and therefore protected. ${ }^{87}$ Both propositions are questionable in the case of attorneys and almost certainly wrong if applied to physicians. The severe effects of expulsion from a medical society and the reputational damage that may result from even a successful defense of an ethical charge are more than sufficient to provide a substantial chill. The truth or falsity of an advertisement may be a simple matter for the advertiser to determine if the question is one of price charged for a standardized service; it is not so easy if the issue is whether there is sufficient disclosure to protect the consumer from being misled concerning the necessity for treatment.

It seems unlikely, however, that the Supreme Court will modify its ruling regarding overbreadth. It adhered to its existing position in Ohralick. ${ }^{88}$ The Court has become increasingly hostile to the doctrine even in more typical first amendment cases ${ }^{89}$ and has an understandable preference for deciding only the issues presented on the record of each case. It is not surprising that in scaling down the normal first amendment protections to fit what it considers the lesser category of commercial speech, the Court chose overbreadth as one of the first things to go. As a result, the boundaries of permissible regulation of physician and lawyer advertising will be hammered out over an extended period of time, case by case and issue by issue.

2. False or Misleading Advertisements. Political speech cannot be banned on the ground that it is false; it is up to the listener to make up his own mind as to what constitutes political truth. Too much speech would be chilled if political speakers had to guess at what some future jury might determine to be false. ${ }^{90}$

In extending the protection of the first amendment to commercial speech, however, the Supreme Court has assumed from the beginning that false advertising could continue to be prohibited. ${ }^{91}$ The reasons are the same as those offered by the Bates Court in refusing to allow third parties to attack restraints on professional advertising on grounds of overbreadth: commercial speech is thought less subject to the chilling effect and whether the advertisement is truthful is thought to be easily ascertainable by the advertiser. ${ }^{92}$ As already stated, these propositions

87. Id.

88. See text accompanying notes 62-66 supra for a discussion of the case.

89. See Broadrick v. Oklahoma, 413 U.S. 601 (1973).

90. See Gertz v. Robert Welch, Inc. 418 U.S. 323, 339-41 (1974); New York Times Co. v. Sullivan, 376 U.S. 254, 279 (1964).

91. See Bates, 433 U.S. at 383; Virginia State Bd. of Pharmacy, 425 U.S. at 771-72.

92. 433 U.S. at 383; Virginia State Bd. of Pharmacy, 425 U.S. at 771 n.24. 
are far from self-evident. Only recently, an advertisement for acupuncture might well have been condemned as false advertising in the United States. An argument can be made for letting the consumer decide the truth or falsity of at least some medical advertising. On the other hand, much objective advertising is easily subject to factual proof or disproof and an advertiser should arguably have a duty to verify his statements before publishing them. In any event, it is clear as a practical matter that false and misleading advertising will continue to be subject to prohibition.

The difficulties of enforcement lie in fixing standards for misleading or deceptive advertisements. The Court in Bates suggested that because the public lacked sophistication with regard to legal services, "misstatements that might be overlooked or deemed unimportant in other advertising may be found quite inappropriate in legal advertising." 93 The Court indicated that some form of disclaimer might properly be required even in connection with the Bates advertisement. ${ }^{94}$ Certainly the same admonitions could be applied to physician advertising. There can be little disagreement with regulations condemning advertisements which create unjustified expectations, as with a "sure cure" for many illnesses. ${ }^{95}$

There is a danger, however, that too stringent a standard may be applied if the underlying first amendment considerations are not kept firmly in mind. Virtually any advertisement is capable of misleading someone, and virtually any advertisement can be made less misleading by the addition of numerous and detailed disclaimers. Advertisements by their very nature simplify, and all simplification contains an element of potential deception. The important point for the regulating body to keep in mind is that the protection of commercial speech is based upon a balancing process. An advertisement should not be condemned per se merely because it is capable of deceiving someone. That is but one side of the scale; it may or may not outweigh the interest of other individuals in receiving the information contained in the advertisement-an interest that must be thrown into the balance as well. Also to be considered are the ease with which the misleading tendency can be avoided and the degree to which elimination of the misleading portion or punishment for publication may chill the dissemination of information. In short, the regulatory body must give some weight to the new element that has been injected into the law of false advertising-the

93. 433 U.S. at 383.

94. Id. at 384 .

95. Such advertising has already been condemned by the AMA. Statement of the Judicial Council Re: Advertising and Solicitation, supra note 27, at 2328. 
first amendment interest in the dissemination of information. ${ }^{96}$ The Supreme Court's own performance in protecting the advertisement in Bates is an appropriate model; the advertisement could have been made less misleading by a statement that an attorney is not essential for a name change and by a precise and detailed description of what was meant by "legal clinic." Neither disclaimer was required, at least in the absence of a much stronger showing of need. The Court is likely to show the same tolerance if it is called upon to deal with physician advertising.

3. Advertisement of Quality of Services. The Bates Court did not determine the permissibility of advertisements of quality of services, with the caveat that such claims are not susceptible of verification and thus may be so misleading as to warrant restriction..$^{97}$ While the Court's language suggests sympathy toward a prohibition, there are many varieties of advertisements of quality, and some of them should be protected. Puffing of the "best physician in town" variety is most likely what the Court had in mind as a candidate for prohibition. But an advertisement stating that a physician has been in practice a certain number of years, that he is certified in a specialty and that he graduated from a prestigious medical school is certainly an advertisement that suggests a high quality of services; the information has little other use. The advertisement is by almost any definition "self-laudatory."98 Yet it conveys precisely the kind of information that a consumer of medical services is entitled to know. Thus first amendment standards will not be met by a regulation which prohibits all advertisement suggesting a high quality of service or containing self-laudatory material. If the objective statements are reasonably subject to verification, implications of quality should be permissible.

One variety of advertisement implying quality that is specifically disapproved by the new AMA standards is the testimonial. ${ }^{99}$ It is ar-

96. For recent cases that wrestle with first amendment commercial speech doctrines in the FTC false advertising context, see Warner-Lambert Co. v. FTC, 562 F.2d 749 (D.C. Cir. 1977); FTC v. National Comm'n on Egg Nutrition, 517 F.2d 485 (7th Cir. 1975), cert. dentied, 426 U.S. 919 (1976).

97. 433 U.S. at 383-84.

98. The Statement of the Judicial Council of the AMA condemns as "solicitation" attempts to obtain patients with statements that "are self-laudatory and imply that the physician has skills superior to other physicians engaged in his field or specialty of practice." Statement of the Judicial Council Re:Advertising and Solicitation, supra note 27, at 2328. The ethical considerations recommended by the ABA after the Bates decision include the comment that "self-laudation should be avoided." ABA Proposal on Lawyer Advertising (Proposal A), EC $2-8$ (1977).

99. The testimonial is condemned by the AMA as another form of solicitation. Statement of the Judicial Council Re: Advertising and Solicitation, supra note 27, at 2328. 
gued that a person might quite honestly state that "Dr. Jones cured my problem in six weeks," but the cure may not be attributable to anything done by Dr. Jones; furthermore, the fact that Dr. Jones cured one person in six weeks is irrelevant to what he can do for another person. ${ }^{100}$ The argument has considerable surface plausibility. Its difficulty is that the traditional way of choosing doctors, favored by those who would limit advertising, is for the potential consumer to ask friends and neighbors for a physician who has given them satisfactory service; that is, to solicit just such testimonials. To be sure, it might be preferable for the consumer to seek recommendations of quality from physicians about other physicians (assuming candor would survive professional courtesy), but most consumers do not have access to that kind of opinion. Since the lay person's testimonial is the next most satisfactory selection tool, it is not readily apparent why an advertised testimonial might not be equally useful. Perhaps it is feared that the economic motive would create a temptation to give false testimonials and that testimonials selected by the provider would likely present an unbalanced picture.

On its face, one may also question the assertion that the success of one cure is not relevant to the potential success of others. The deficiency of the typical testimonial is not lack of relevance but insufficiency of sample. One hundred consecutive appendectomies without a complication would certainly not be irrelevant to the likelihood of a hundred-and-first. Moreover, it is more consistent with the first amendment theory of commercial speech for the regulators to concern themselves with truth in advertising and to permit the consumers to be the judge of relevance. If that approach is not always practicable in the field of medicine, it is nevertheless a reasonable goal in the common run of cases.

Comparative advertising is a subspecies of advertisement of quality that is also condemned by the new AMA rules. Here again, the condemnation is too restrictive; the AMA would condemn statements that are "self-laudatory and imply that the physician has skills superior to other physicians engaged in his field or specialty of practice." ${ }^{101}$ Such a restraint is probably reasonable as applied to the "best physician in town" advertisement, but not to the advertisement (admittedly a rarity) which states that a physician has twenty-five years of practice while the other physician in town has only two. The latter information may be distasteful to the second physician but it contains information that would almost certainly be relevant to the selection of a physician either

100. Brief for the AMA, supra note 25, at 6 .

101. Statement of the Judicial Council Re: Advertising and Solicitation, supra note 27, at 2328. 
by a lay person or by a fellow physician. The admonition of the Bates Court that some information is better than none would seem to apply. If the information is sufficiently factual to be subject to verification, it should be protected despite reasonable implications of quality that might be drawn from it.

4. Radio and Television Advertising. The Court in Bates simply stated that "the special problems of advertising on the electronic broadcast media will warrant special consideration." 102 It is difficult to see, however, how the two characteristics of the electronic media thought to have the most significance for purposes of the first amendment-the limitation of spectrum space and the greater impact of the me$\mathrm{dia}^{103}$ - have any particular relevance to the reasoning of the Bates Court. Indeed, radio and television have a much greater potential than print for reaching the audience least likely to have knowledge of or access to attorneys or physicians. This consideration led the ABA to recommend that radio advertising be permitted, ${ }^{104}$ and the case for radio advertisement by physicians seems equally strong.

Television advertising was not recommended by the ABA; it was suggested that the state regulatory bodies permit such advertising only upon a special showing that the public interest would be served by it. ${ }^{105}$ Television was thought to present special problems of emphasizing style over substance, excessive cost and difficulty of monitoring. The latter two objections can be quickly dismissed. Television advertising is likely to be utilized only to the extent that it represents a reasonable cost per viewer compared with other methods of advertising. Monitoring can be managed by requiring advertisers to keep tapes or transcripts of commercials. The question of style is more complex, but ought not to be regarded as a justification for banning television advertising. The problem, once again, is determining who may decide what is relevant for purposes of choosing lawyers or physicians. Admittedly, television conveys an image of the person who appears on it, so that a potential patient might decide that he likes the physician's appearance, voice or attitude. The organized profession may well feel, as the ABA does, that such considerations are irrelevant to the choice of a professional and that this information therefore should not be made available to consumers. But a strong first amendment argument can be made to

102. 433 U.S. at 384.

103. See Red Lion Broadcasting Co. v. FCC, 395 U.S. 367, 388-89 (1969); Banzhaf v. FCC, 405 F.2d 1082, $1100-01$ (D.C. Cir. 1968), cert. denied, 396 U.S. 842 (1969). (1977).

104. ABA Proposal on Lawyer Advertising (Proposal A) (1977), excerpted, 63 A.B.A.J. 1234

105. Id. 1235. Proposal B, which was not adopted, contains a similar provision. Id. 1236. 
the contrary: to a person seeking to enter a professional relationship of confidence and trust it is highly relevant whether he is at ease in the presence of his doctor or lawyer. Indeed, a lay person who is acquainted personally with physicians whom he deems to be competent may well select the one he thinks has the best bedside manner. That consideration may be quite relevant to the effectiveness of the professional relationship. The best approach under the first amendment would be to leave the question of style to the consumer; some may like flamboyance and some conservatism. There is no legitimate reason why they should be deprived of the choice by a regulating body. A total ban of television advertising is certainly more than is necessary to control such an evil, even assuming that it is indeed an evil.

5. Time, Place and Manner Restrictions. The Supreme Court has indicated that professional advertising, like other speech, may be subject to reasonable restrictions regarding time, place and manner. ${ }^{106}$ This issue is likely to arise in two situations. First, methods of advertising thought to be lacking in dignity or restraint would probably be subject to sanction, but with dubious propriety. A neon sign might not seem particularly dignified, but that fact alone does not justify a prohibition. Dignity relates to content, not manner. If the neon sign is also a traffic hazard, that is an entirely different manner, but such restrictions hardly need be addressed especially to professional advertising.

A second problem of time, place or manner restriction arises in the case of advertisement or solicitation of accident victims at the time and place of the accident or immediately thereafter. It was in such a setting that the Supreme Court upheld a ban upon in-person solicitation by lawyers. ${ }^{107}$ On the other hand, the dangers are undoubtedly less severe in the case of doctors than of lawyers. If the emergency is a true one and a physician appears on the scene, his immediate employment will almost certainly be considered a benefit by all concerned. If more permanent employment is solicited, it would be reasonable for a regulating body to impose some restrictions designed to insure that persons not be importuned at a time when their physical distress is likely to deprive them of the faculty of rational choice.

Other limitations of time, place and manner may suggest themselves as the Court further adjudicates the boundaries of permissible regulation. It seems clear, however, that here as elsewhere the first amendment considerations ruled upon or hinted at in Bates preclude generalized prohibitions based upon professional traditions. Bates has

106. Bates, 433 U.S. at 383.

107. See note 66 supra and text accompanying notes $62-66$ supra. 
tipped the constitutional scales in favor of the dissemination of information about physicians' services and fees, and that fact will permeate future decisions on the regulation of advertising. The remaining issues are the degree to which the antitrust laws may apply to the subject of physician advertising and the differing considerations they may introduce.

\section{Application of the Antitrust Laws to Physician ADVERTISING}

The antitrust challenge to prohibitions against lawyer advertising in Bates foundered because the disciplinary rule was held to be an affirmative command of the state. ${ }^{108}$ The rule was required by the state supreme court and, therefore, that court was the real party in interest. Under this characterization, the Supreme Court ruled that the federal antitrust laws could not be applied since they were not intended by Congress to preempt state action. ${ }^{109}$ Consequently, the Court did not have to determine whether Arizona's total ban of price advertising by lawyers was a per se violation of the Sherman Act or whether it should be tested under the rule of reason evaluating the impact of the prohibition on the market for lawyers' services.

Two factors may justify a substantially different approach to restrictions on physician advertising. First, as already noted, ${ }^{110}$ no clearcut judicial or other state command underlies many restrictions on physician advertising. Thus, the question whether the federal antitrust laws apply to such advertising proscriptions presents more complex and sophisticated issues. Second, if the antitrust laws generally do apply to restrictions on physician advertising, it is far from clear that all such restrictions (including prohibitions of price advertising) would violate the Sherman Act. Indeed, persuasive arguments can be made that these advertising restrictions should be tested in accordance with a rule of reason approach.

\section{A. Jurisdictional Issues.}

In Goldfarb v. Virginia State Bar, ${ }^{11}$ the Supreme Court held that a state bar association's enforcement of a minimum fee schedule published by a county bar association amounted to price fixing and therefore violated the Sherman Act. Prior to this 1975 ruling, most

108. 433 U.S. at 361.

109. Id. at 359-63.

110. See text accompanying note 26 supra.

111. 421 U.S. 773 (1975). 
professionals and professional associations assumed that they were outside the target area of antitrust liability. Few complaints had been brought against lawyers, physicians, engineers or architects by either government agencies or private parties. And in most instances the actions of professionals were not even reviewed because the courts quickly dismissed such lawsuits. ${ }^{12}$

The reason for the absence of antitrust action against medical societies or other professional groups or individuals is that the claimant had to overcome three basic hurdles before the substantive complaint could be heard. First, the claimant had to show that the defendants' activity substantially affected interstate or foreign commerce. Second, the claimant's action was barred entirely if the defendants were participants in a learned profession exempt from the antitrust laws. Third, the claimant had to ascertain whether the particular actions being challenged were mandated or supervised by state agencies and were therefore within the state action limitation on the antitrust laws. For a long time these barriers to an antitrust complaint seemed insurmountable. Today only the last remains effective and its application as a bar to such actions has been reduced.

1. Interstate Commerce. The first hurdle, that interstate commerce must be affected before the antitrust laws can be invoked, follows from the language of the Sherman Act focusing on restraints or monopolization of "trade or commerce among the several states." 113 It is, moreover, a constitutional requirement since Congress can regulate only where the activity affected is within or has a significant effect on the flow of interstate commerce. ${ }^{114}$ The issue, then, is whether the professional service being challenged-for example, the refusal of a medical society to approve physician advertising of prices-is essentially local in nature. If viewed as a local service, the restraint on the physician's services usually will not be held to have a substantial effect on interstate commerce. In most situations a physician's treatment of patients is localized and is neither in interstate commerce nor likely to affect it in any substantial respect. That, at least, was the argument paralleled by the county bar association in Goldfarb when minimum fee schedules for title searches were under attack. The Supreme Court did

. 112. E.g., Rigell v. Washington County Medical Soc'y, 249 F.2d 266 (8th Cir.), cert. denied, 355 U.S. 954 (1958); cf. Estate of Freeman v. Freeman, 34 N.Y.2d 1, 355 N.Y.S.2d 336, 311 N.E.2d 480 (1974) (practice of law is a profession rather than a business and minimum fee schedule of county bar association therefore not subject to state antitrust law).

113. 15 U.S.C. $\$ 1$ (1976).

114. See United States v. South-Eastern Underwriters Ass'n, 322 U.S. 533, 558 (1944) (Sherman Act interpreted as going "to the utmost extent of [Congress'] Constitutional power."). 
not accept this contention, however, because the title searches were found to be intimately related to and, indeed, inseparable from mortgage loans frequently guaranteed by the federal government. Thus, minimum title search fees did in fact substantially affect interstate commerce. ${ }^{115}$

For a time, albeit briefly, it could have been argued that only those professions intimately related to general business activity-for example, law, engineering and architecture-were subject to this interpretation and that other professions less clearly related to commercial activity-primarily medicine and dentistry-might still be protected because of the Court's emphasis on "the substantial volume of commerce involved." 116 However, in 1976 in Hospital Building Co. v. Trustees of Rex Hospital, ${ }^{117}$ the Court clearly established that it would read antitrust complaints liberally in order to find the necessary nexus between the challenged conduct and interstate commerce. ${ }^{118}$ In that case, one hospital's effort to block the relocation and expansion of another hospital, all within the city limits of Raleigh, North Carolina, was held to have placed an "unreasonable burden on the free and uninterrupted flow" of commerce because these activities could affect purchases of out-of-state medicines and insurance as well as payments to out-ofstate managers and lenders. ${ }^{119}$ Under this line of reasoning, any restraint on physician services, including advertising prohibitions, would seem to have the requisite effect on commerce. Therefore, the requirement that restraints on physician services affect interstate commerce does not generally bar application of the antitrust laws to their activities. $^{120}$

2. Learned Professions. The second impediment to an antitrust complaint against physicians or lawyers had been the argument that they are members of learned professions which are not within the "trade or commerce" language of the Sherman Act. In other words, it was argued that the professions were service- rather than profit-oriented and thus were not business activities intended by Congress to be within the purview of the antitrust laws. The ethical canons of these professions nobly state that money-making is not their aim; rather, it is the duty of every doctor and lawyer to provide necessary services to the

115. Goldfarb, 421 U.S. at $783-85$.

116. Id. at 785 .

117. 425 U.S. 738 (1976).

118. Id. at 742 n.1.

119. Id. at 746 .

120. Accord, Boddicker v. Arizona State Dental Ass'n, 549 F.2d 626, 629 (9th Cir.), cert. denied, 434 U.S. 825 (1977). 
community. ${ }^{121}$

This primary service goal of lawyers, physicians and similar professions has been the traditional basis for distinguishing professions from trades or business in other areas. This distinction has been recognized in occasional language in judicial opinions, as in the Supreme Court's statement that "medical practitioners . . . follow a profession and not a trade." 122 Thus, the learned profession exemption seemed to be the most promising defense available when local bar association rules were first challenged on antitrust grounds in Goldfarb. But the argument that lawyers were not profit-oriented lost much of its force when relied upon to save a minimum fee schedule, since the schedule was obviously designed to eliminate price competition and to increase profits. It became a simple matter for the Court to conclude that title examinations were services provided by lawyers in exchange for money and that their activities were "commerce" under the Sherman Act. According to the Court, "[i]t is no disparagement of the practice of law as a profession to acknowledge that it has this business aspect."123

While an effort might still be made to distinguish physician services from legal services, such efforts seem doomed. Even accepting without question the altruistic motives and public service notions commonly attributed by physicians to their own efforts, it cannot be denied that profit is more than an incidental by-product of the medical profession. Fee schedules, as well as relative value scales, are not unknown to doctors. If there were any question as to this conclusion, it was dispelled by the Court's recent rejection under the first amendment of the bar's argument in Bates that price advertising would commercialize the practice of law and undermine the professionalism of the bar. Describing this argument as simple-minded self-deception, the Court noted that it incorrectly "presumes that attorneys must conceal from themselves and from their clients the real-life fact that lawyers earn their livelihood at the bar."124 The Court's dismissal of the contention that lawyers are somehow not involved in a commercial trade and are "above it all" seems to foreclose further reliance on the argument that the medical profession can join professional baseball ${ }^{125}$ in a privileged

121. See Goldfarb, 421 U.S. at 786-88.

122. FTC v. Raladam Co., 283 U.S. 643, 653 (1931). See cases cited in Goldfarb, 421 U.S. at 786 n.15.

123. Goldfarb, 421 U.S. at 788.

124. 433 U.S. at 368.

125. See Federal Baseball Club v. National League, 259 U.S. 200, $208-09$ (1922) (organized baseball held not to be commerce); Flood v. Kuhn, 407 U.S. 258, 282 (1972) (baseball's exemption continued on grounds of stare decisis). But $c f$. Radovich v. National Football League, 352 U.S. 445 (1957) (professional football held to be commerce subject to antitrust laws). 
sanctuary untouched by the antitrust laws.

3. State Action-the Parker Doctrine. The third argument that has been offered to protect professional services and their regulation from antitrust scrutiny, the "state action" doctrine, is different from the first two jurisdictional defenses in that it retains vitality and is the center of continuing dispute. Based upon a 1943 decision, Parker $v$. Brown, ${ }^{126}$ the doctrine provides that the Sherman Act was intended by Congress to regulate only private practices restraining trade. The Parker Court determined that state legislatures were not prevented by the federal antitrust laws from regulating market practices within their states. For this exemption from the Sherman Act to apply, the competitive restraint must be imposed as a governmental action. Thus, the Parker Court upheld, against an antitrust challenge, a California program regulating the marketing of raisins which denied producers free access to potential buyers of their crops. ${ }^{127}$ Even though private individuals have engaged in price fixing or other anticompetitive conduct, their actions will be attributed to the state and exempted from antitrust liability if they are mandated and supervised by a state agency. ${ }^{128}$ Parker held that the antitrust laws did not prevent the states from substituting economic regulation for the free market preference of the Sherman Act. ${ }^{129}$

This rule was ostensibly based upon Congress' intent in adopting the Sherman Act. ${ }^{130}$ Although the Court was undoubtedly accurate when it said that nothing in the Act or its history supported a conclusion that the purpose was to restrain state action, similar reasoning starting from a polar premise could have suggested a contrary conclusion. Under such an analysis, the policy of the Sherman Act would be interpreted as preventing states from permitting or requiring, directly or indirectly, anticompetitive conduct such as price fixing; nothing in the legislative history exempted state action. This was, indeed, the position of the Justice Department, which filed a brief asserting that the

126. 317 U.S. 341 (1943).

127. In fact, Parker involved neither a direct governmental action nor a Sherman Act suit. The plaintiff had filed an equitable complaint seeking to enjoin state officers from enforcing the state raisin program, in part because it contravened the policies and requirements of the Sherman Act. When the Court ruled that the Sherman Act had not been violated, the equitable action failed.

128. 317 U.S. at 352.

129. Id. at $350-51$.

130. "The Sherman Act makes no mention of the state as such, and gives no hint that it was intended to restrain state action or official action directed by a state." Id. at 351. 
state program was inconsistent with the Sherman Act ${ }^{131}$ (though not with federal agricultural legislation). The Parker doctrine was undoubtedly meant to be an accommodation to state interests in occupational licensure and other market regulation programs which had previously been invalidated under the discredited line of cases which used substantive due process as a method for overturning numerous efforts at government regulation. ${ }^{132}$

Applied to the professions, the state action exemption arguably protects regulation carried out under the auspices of a state agency or court or through an "integrated" (mandatory) association, as in the case of lawyers, or possibly by state boards of accountancy or medical examiners, as is the rule for other professional regulation. ${ }^{133}$ On the other hand, the Parker doctrine specifically relied on the fact that the state's program "derived its authority from the legislative command of the state and was not intended to operate or become effective without that command." 134 That underlying command seems absent in much professional regulation where canons of professional ethics are drafted. In medicine, for example, the canons are written by the AMA and often enforced by local private medical societies, hospitals and, indirectly, by malpractice insurers. Moreover, Parker itself states two limi-

131. Brief for the United States as Amicus Curiae at 53-59, Parker v. Brown, 317 U.S. 341 (1943).

132. For a careful examination of this thesis, see Verkuil, State Action, Due Process and Antitrust: Reflections on Parker v. Brown, 75 Colum. L. Rev. 328 (1975). See also Handler, The Current Attack on the Parker v. Brown State Action Doctrine, 76 Colum. L. Rev. 1 (1976). We disagree, however, with the analyses and conclusions offered by both Verkuil and Handler. See note 206 infra.

133. The role of the state bar associations in enforcing ethical restraints is partially dependent upon the legal structure of the particular association and its relation to the courts of the state. In some states the bar association is a voluntary private organization and membership is not a prerequisite for the practice of law. Such voluntary associations normally have committees that issue opinions on questions of ethics. These opinions and other positions taken by the association may have a persuasive effect on the courts, but the connection remains unofficial, and the actual disciplinary enforcement lies with the judiciary. A different and increasingly prevalent pattern for bar associations, however, is that of the "integrated" state bar such as that involved in Bates. The State Bar of Arizona is established by statute, ARIz. REv. STAT. § 32-231 (1976), and court rule, ARIz. SUP. CT. R. 27. Membership in the bar is a requirement for the practice of law, ARIz. REv. STAT. § 32-26I (1976); ARIZ. SUP. CT. R. 27(a)(3). Investigation and prosecution of ethical violations are in the hands of the State Bar, and initial disciplinary hearings are conducted before one of its committees. ARIZ. REv. STAT. § 32-269 (1976); ARIz. SUP. CT. R. 32-35. Fully contested cases are ultimately reviewed by the state supreme court, which has the sole power to impose suspension or disbarment. ARIz. SUP. CT. R. 36-37.

134. 317 U.S. at 350 . Immunity is conferred only when the anticompetitive policy is mandated by the state; the actions of a municipality are not immune in the absence of such a state policy. City of Lafayette v. Louisiana Power and Light Co., 98 S. Ct. 1123 (1978). See generally Note, Antitrust Laws and Municipal Corporations: Are Municipalities Exempt from Sherman Act Coverage Under the Parker Doctrine?, 65 GEO. L.J. 1547 (1977). 
tations on its holding. First, a state cannot immunize private action merely by authorizing private individuals to violate the Sherman Act; ${ }^{135}$ the state must both organize and enforce the program. Second, Parker did not involve a situation where the state was "a participant in a private agreement" to restrain trade. ${ }^{136}$ These two exceptions as well as the inherent ambiguities in Parker have become prominent in recent Supreme Court decisions. One must look to these cases for guidance in determining whether legal constraints on physician advertising would now be subject to antitrust scrutiny.

Goldfarb was the first of a trio of major Court cases in this area. ${ }^{137}$ The issue in that case was whether a minimum fee schedule applicable to all lawyers violated the Sherman Act. The schedule had been drawn up by a voluntary county bar association and its enforcement was the responsibility of the mandatory state bar association. ${ }^{138}$ Although the schedule had in fact never been formally enforced in a disciplinary action, the plaintiffs had been unable to find a lawyer willing to charge less, despite an extensive search, ${ }^{139}$ the state bar had published reports and opinions supporting fee schedules and in one such opinion had ruled that an attorney who "habitually" charges less than the minimum is presumed to be guilty of misconduct. ${ }^{140}$ Notwithstanding that the state bar association was a state agency by law, it was far from certain that the state supreme court (which was granted the authority to regulate the practice of law and had delegated investigation and enforcement responsibility to the state bar) had in fact required the anticompetitive activities. The Court concluded:

Respondents' arguments, at most, constitute the contention that their activities complemented the objective of the ethical codes. In our view that is not state action for Sherman Act purposes. It is not enough that, as the County Bar puts it, anticompetitive conduct is "prompted" by state action; rather, anticompetitive activities must be compelled by direction of the State acting as a sovereign. ${ }^{141}$

The Court held that the fee schedule was "essentially a private anticompetitive activity" unprotected by the Parker doctrine. ${ }^{142}$

Nevertheless, the Court's ruling late in the next term that Virginia's statute forbidding the advertising of prescription drugs infringed

135. 317 U.S. at 351; see Schwegmann Bros. v. Calvert Distillers Corp., 341 U.S. 384, 38687, 389 (1951); Northern Securities Co. v. United States, 193 U.S. 197, 332, 344-47 (1904).

136. 317 U.S. at $351-52$.

137. See text accompanying note 111 supra.

138. 421 U.S. at 776.

139. Id.

140. Id. at 777-78.

141. Id. at 791.

142. Id. at 791-92. 
the first amendment rights of retail druggists included a comment that the state action doctrine had not been abandoned:143 "Virginia is free to require whatever professional standards it wishes of pharmacists; it may subsidize them or protect them from competition in other ways." 144

Exactly what this statement meant or what was covered by the Goldfarb test exempting anticompetitive conduct "compelled by direction of the state" was the subject of extensive discussion by the Court just six weeks later. ${ }^{145}$ In Cantor v. Detroit Edison Co., ${ }^{146}$ the Court declined to shield from antitrust attack a public utility's program whereby new light bulbs were exchanged for burned-out bulbs. In contrast to the Court's opinion, the facts in Cantor are simple. For eighty years, Detroit Edison had distributed light bulbs to its customers without charge "to increase the consumption of electricity." 147 This exchange program had been included in its tariffs filed with the Michigan state regulatory agency for sixty years. Because the state agency approved the utility's rate structure and supervised its actions closely, the lower courts had dismissed the complaint; they viewed the case as being squarely within the Parker doctrine. ${ }^{148}$ When the case came to the Supreme Court, however, it was equally clear that the lower courts had not correctly understood the gloss which Goldfarb had added to the state action rule. This confusion was demonstrated by the Justices themselves as they divided into four factions with no opinion commanding more than four votes. ${ }^{149}$

In interpreting the opinions in Cantor, two points need to be noted. First, six of the nine justices found that the state action doctrine was inapplicable. ${ }^{150}$ Those refusing to apply it to the bulb exchange program relied primarily on the fact that the state had sought to regulate only the distribution of electricity, not the marketing of light

143. Virginia State Bd. of Pharmacy v. Virginia Citizens Consumer Council, 425 U.S. 748 (1976).

144. Id. at 770

145. Cantor v. Detroit Edison Co., 428 U.S. 579, 592-95 (1976).

146. 428 U.S. 579 (1970).

147. Id. at 584 .

148. Id. at 581 .

149. However, the Chief Justice did join with the plurality in Part III of the opinion which stated that private conduct required by state law may be exempt from the Sherman Act to the minimum extent necessary to make the state regulation work. But he could not agree that the Parker immunity was limited to official action taken by state officers. Id. at 603 .

150. Justice Stevens' discussion of the state action question was joined by only Justices Brennan, White and Marshall. Id. at 581. However, both Chief Justice Burger and Justice Blackmun wrote concurring opinions. Id. at 603,605 . 
bulbs. ${ }^{151}$ The utility had initiated the exchange program and apparently was free to abandon it upon the filing of a new tariff. Thus, it did not seem unfair to the Court that the utility should be required to bear the antitrust consequences of its program. Second, no statement of the state action doctrine could command a majority of the Supreme Court. A plurality of four read Parker as being limited to upholding only the antitrust immunity of official action taken by state officials. ${ }^{152}$ Their opinion did not read the state action doctrine as applying to private conduct not dominated by the state. Yet this same plurality stated no corresponding rule and left it wholly unclear what the boundaries of the doctrine (beyond the Parker minima) might be, if any. Chief Justice Burger, who concurred in the plurality's conclusion as well as in much of its opinion, would have reiterated the standard he announced in Goldfarb, namely that the issue was whether the challenged conduct was required by the state acting in its governmental capacity. ${ }^{153}$ Four Justices would have looked instead at the congressional intent to exempt or include the private conduct, although this group disagreed among themselves as to whether Congress intended to preempt state regulation of private conduct. ${ }^{154}$

After the Cantor decision, the law appears to be unduly confused. Indeed one commentator has gone so far as to say that "[a]fter Cantor, it was anyone's guess whether there was a state action defense and if there was, what its scope might be." ${ }^{155}$ However, both the Goldfarb and Cantor decisions appear to presage closer scrutiny by the Court of efforts to immunize private conduct from antitrust liability by masquerading it as state action. The Court clearly seems concerned with private domination of markets through the use (and abuse) of state agencies. Thus, where the decision making is in fact controlled by private individuals or groups, especially in the furtherance of their special interests, it will not be exempt from the reach of the Sherman Act. The Court seems to be saying that what individuals cannot do privately, they cannot do under "cover" of state law.

The Bates opinion reinforced this interpretation of the law. Again, however, the Court did not announce a standard for determining the degree of state compulsion required for a finding of state action where private conduct was involved, undoubtedly because the Justices still

151. Id. at 584-85 (opinion of Stevens, J.); id. at 604-05 (Burger, C.J., concurring); id. at 61214 (Blackmun, J., concurring).

152. Id. at $591,601-02$.

153. Id. at 604 .

154. Id. at 605 (Blackmun, J., concurring); id. at 632 (Stewart, J., dissenting).

155. Handler, Changing Trends in Antitrust Doctrines: An Unprecedented Supreme Court Term-1977, 77 ColUM. L. Rev. 979, 1013 (1977). 
could not agree on the applicable legal standard. On the other hand, the factors relied upon by the Court are instructive. The antitrust claims in Bates were viewed as being directed against the state court even though the state bar was the nominal defendant. The state's interest in regulating advertising was well established; the attorneys challenging the no-advertising rule had conceded that false or misleading ads were a legitimate subject of state regulation as against both antitrust and first amendment claims. The regulation of lawyer advertising was actively pursued by the state bar and court. As a result, "concern that federal policy is being unnecessarily and inappropriately subordinated to state policy is reduced."156

Restating these points as a legal test, whether private conduct subject to some state control is within the state action exemption now appears to rest on the answer to three questions. First, is the state the real party in interest in the lawsuit? Second, does the state have an independent regulatory interest in the challenged activity? Finally, does the disputed conduct reflect a clear articulation of state policy rather than a mere acquiescence by the state in the program? The Court is obviously reluctant to impinge on state sovereignty. Yet there are limits to what it will tolerate. Thus, the state action exemption will be applied only where the state, acting in its governmental capacity, has played a significant role in the challenged activity. What further evolution the doctrine will undergo is uncertain.

Before suggesting how the state action doctrine might apply to advertising restrictions on physician services, a question could be raised as to whether the matter has not already been answered by our earlier analysis of the first amendment challenge. It might be argued that if the state connection to these restraints is sufficient to invoke the fourteenth amendment, ${ }^{157}$ it is also necessarily sufficient to constitute Parker state action. However, "state action" as applied to the fourteenth amendment and to the Sherman Act are not synonymous. First, the legal standards of requisite state action are not at all identical or even similar. The policy behind the first amendment requires that it be read liberally and applied broadly. Hence, almost any conduct that is coerced or encouraged by the state is subject to first amendment challenge. The policy behind the Parker doctrine, on the other hand, seeks to accommodate legitimate state interests in protecting its citizens from undesirable conduct while recognizing national policies favoring free and open competition in most markets. ${ }^{158}$ There is, in addition, serious con-

156. 433 U.S. at 362.

157. See notes $30,33 \& 35$ supra and text accompanying notes 30-36 supra.

158. See 428 U.S. at 596-97. 
cern that state sovereignty be preserved and that the courts not reverse state regulation merely because of differing economic perceptions. ${ }^{159}$ Consequently, the state action concept in antitrust law applies a much higher - and as yet, unclear-threshold. And it is not necessarily inconsistent to say that conduct which constitutes state action for first amendment purposes is not within the ambit of the Parker exemption. Second, different conduct may be at issue. Advertising restraints imposed by state boards may fall only before a constitutional challenge whereas similar prohibitions established by local medical societies or private hospitals may be subject only to antitrust liability.

As this discussion suggests, the particular facts in each case are critical in deciding whether rules preventing advertising by physicians are within the reach of the antitrust laws. The focus of this Article is on the legal restraints on physician advertising, and therefore we do not explore in depth all the possible areas where such restraints might exist. The foundation for the various restraints on advertising, however, appears to be section 5 of the AMA's Principles of Medical Ethics, which provides, in part, that a physician "should not solicit patients." 160 As already noted, ${ }^{161}$ this canon is still widely read by physicians and local societies as barring all physician advertising, despite a recent AMA interpretation that physicians may advertise but may not engage in advertising practices which amount to solicitation of patients by false or deceptive statements. ${ }^{162}$ Even prior to its latest interpretation, the AMA itself has not been directly enforcing a restraint; in the last thirty-five years it has never disciplined a member for violation of section 5 of its ethical principles. In the one section 5 case to reach its Judicial Council, the Council reversed a state society's holding that a health care group's advertising violated AMA principles. ${ }^{163}$

But it also seems clear, from the briefs filed by complaint counsel and especially by the AMA's counsel in the current FTC litigation, ${ }^{164}$

159. The Parker Court made this point clearly:

We find nothing in the language of the Sherman Act or in its history which suggests that its purpose was to restrain a state or its officers or agents from activities directed by its legislature. In a dual system of government in which, under the Constitution, the states are sovereign, save only as Congress may constitutionally subtract from their authority, an unexpressed purpose to nullify a state's control over its officers and agents is not lightly to be attributed to Congress.

317 U.S. at 350-51.

160. See text accompanying notes $23-24$ supra.

161. See text accompanying note 24 supra.

162. Statement of the Judicial Council Re: Advertising and Solicitation, supro note 27, at 2328.

163. Matter of Ben E. Landess, AMA Opinions and Reports of Judicial Council (1955).

164. See Briefs, AMA, FTC Dkt. No. 9064, [1973-76 Transfer Binder] TRADE REg. ReP. (CCH) If 21,068. See also Briefs, American Dental Ass'n, FTC Dkt. No. 9093, [1977] 3 TrADE REG. REP. (CCH) I 21,255 . 
as well as from studies by economists and other social scientists, that numerous examples could be found of national groups (such as the American College of Emergency Physicians), local medical societies, and state boards dominated by private physicians, that have in fact used section 5 to bar advertising which was primarily informative and not misleading. ${ }^{165}$ Whether these prohibitions violate the antitrust laws will be examined later; for now it is enough to conclude that physicians acting in private groups, primarily through local medical societies, have sought to bar all advertising.

The significance of such efforts, and the concern they create as a matter of public policy as well as under specific rules of the Sherman Act, is that disapproval by a medical society invariably goes far beyond private expressions of disagreement. Improper advertising may be declared to be unprofessional conduct and may form the basis for expulsion of participating physicians from membership in the county medical society. While licensing violations are usually enforced by state boards or, in some cases, courts or other government agencies, much of the disciplinary activity short of censure or revocation of a license is the responsibility (by default rather than specific delegation) of the local society. ${ }^{166}$ This power is substantial because of the central importance of membership in this private group. As previously described, ${ }^{167}$ expulsion can have disastrous consequences for the physician.

Even where the advertising ban is promulgated by a state board, it is far from clear that sufficient state action will be involved to establish antitrust immunity. These boards are invariably controlled by physicians and their representatives. For example, in the great majority of states, license boards

are appointed by the governors from a list of names submitted by the state medical society. In two states, the state medical society directly selects the members of the board. In Alabama, the Board of Censors of the state medical society is the state licensing board as well. Thus, the state medical societies are accorded a fundamental role in determining the composition of the state licensing boards. ${ }^{168}$

Enough has been said to support the view that the state action doctrine is unlikely to insulate medicine's general ban on advertising from antitrust challenge. This does not mean that, as currently formulated, most local societies, state boards or even the AMA would be held to

165. See, e.g., Ryacack, The STructure of AMERICAN Industry (W. Adams ed. 1966); A. Nichols, supra note 26, at 54 .

166. A. Nichols, supra note 26 , at 57.

167. See text accompanying note 26 supra. See also Boddicker v. Arizona State Dental Ass'n, 549 F.2d 626 (9th Cir.), cert. denied, 434 U.S. 825 (1978).

168. A. NichOLS, supra note 26, at 50. 
have violated the antitrust laws. It does mean that their rulings on physician advertising are no longer free from outside evaluation.

\section{B. Due Process Limits and Antitrust Principles.}

The fact that ethical rules and other constraints are applied by medical boards and local societies to restrain physician advertising suggests another issue involving the use of the antitrust laws to enforce procedural fairness within private organizations. ${ }^{169}$ It has long been observed that no one should be the judge of his own cause. Thus, in Tumey v. Ohio ${ }^{170}$ the due process clause of the Constitution was held to have been violated when a community's mayor, acting as judge of the mayor's court, received a share of the fines he levied against persons convicted by him. It was too much, the Court said, to expect him, acting in his judicial capacity, always to "hold the balance nice, clear, and true between the state and the accused."171 This requirement of neutrality was extended in Ward $v$. Village of Monroeville ${ }^{172}$ where the mayor again also acted as judge. This time, however, fines and costs were not shared with the mayor but went into the village's treasury. ${ }^{173}$ These levies produced up to half the village budget and the Court was worried that the mayor's judgment, when acting as judge, might be affected by the realization that a decline in court revenues would have to be offset by a decrease in services or an increase in taxes. ${ }^{174}$ The Court therefore held that the possible temptation to bias was enough to disqualify the mayor from acting as judge, notwithstanding that no profit went directly to the mayor. ${ }^{175}$

This principle was applied to state regulatory agencies policing the professions in Gibson v. Berryhill. ${ }^{176}$ In Gibson, corporate employed salaried optometrists sued in federal court to restrain disciplinary proceedings brought against them by the Alabama Board of Optometry, a

169. A related enforcement issue stems from the Noerr-Pennington doctrine. Evolving from the cases of Eastern Railroad Presidents Conference v. Noerr Motor Freight, Inc., 365 U.S. 127 (1961), and UMW v. Pennington, 381 U.S. 657 (1965), the doctrine protects concerted campaigns to petition or influence governmental action from Sherman Act challenges. Efforts by bar associations and medical societies seeking to persuade legislatures to adopt regulatory rules restricting competition clearly raise Noerr-Pennington problems. The case law appears to allow wide latitude to such efforts unless the concerted conduct involves blatantly unlawful efforts at persuasion. See California Motor Transport Co. v. Trucking Unlimited, 404 U.S. 508 (1972).

170. 273 U.S. 510 (1927).

171. Id. at 532.

172. 409 U.S. 57 (1972).

173. $I d$. at 58.

174. Id. at 60 .

175. Id. This holding was not affected by the availability of a trial de novo before an impartial tribunal whenever a dissatisfied defendant appealed from the mayor's court. Id. at 61-62.

176. 411 U.S. 564 (1973). 
state regulatory body whose members were all engaged in private practice. ${ }^{177}$ The Supreme Court held that state board proceedings would have violated the plaintiffs' right to due process because the optometrist members of the board were in financial competition with those being disciplined: "It is sufficiently clear from our cases that those with substantial pecuniary interest in legal proceedings should not adjudicate these disputes." 178

Similar observations could be applied to actions of several state medical boards, especially where the membership is drawn exclusively from lists supplied by organized medicine. Whether such a constitutional challenge would succeed, however, depends specifically upon the particular facts of each case, since Gibson involved a clear-cut case of a state regulatory board controlled by private-practice, fee-for-service optometrists seeking to exclude from the market competing salaried optometrists. Of course, a successful Gibson challenge, being based upon due process, requires that the challenged body be engaged in or infused with state action of the type already described for first amendment purposes. ${ }^{179}$

Even where state action for constitutional purposes is unclear, however, requirements of procedural fairness may be imposed by way of the antitrust laws. Where a profession is delegated self-regulatory authority, such powers can be validly exercised only by observing minimal needs of fair process. In Silver v. New York Stock Exchange, ${ }^{180}$ the Court held that the authority of self-regulation granted the stock exchange in the Securities Exchange Act of 1934 did not exempt the exchange and its members from liability for a group boycott under the Sherman Act. ${ }^{181}$ The lack of fairness in the exchange procedures led the Court to construe the particular act of self-regulation as not immune. "[N]o justification can be offered for self-regulation conducted without provision for some method of telling a protesting nonmember why a rule is being invoked so as to harm him and allowing him to reply in explanation of his position." 182 Thus, the Court held that even where a legitimate and recognized interest exists permitting a restraint on competition, the restraint must be no more restrictive than is necessary to achieve proper objectives and must, in the process, observe fair

177. Id. at 567. The Board had the power to issue, suspend or revoke licenses for the practice of optometry. Id.

178. Id. at 579 .

179. See notes $30,33 \& 35$ supra and text accompanying notes $30-36$ supra.

180. 373 U.S. 341 (1963).

181. Id. at $364-65$.

182. Id. at 361 . 
procedures. ${ }^{183}$

Applied to advertising restrictions used as the basis for sanctions by private medical organizations or individuals acting with others, or by government bodies whose decisions are substantially controlled by physician interests, antitrust liability may result where the restrictions on physician advertising go beyond what is necessary to protect the public. ${ }^{184}$ Moreover, when the procedures of self-regulation do not comport with established requirements of notice, an opportunity to know and challenge adverse evidence, a hearing to present one's own evidence and an unbiased tribunal, antitrust liability may also be imposed. ${ }^{185}$ Now that the doors to antitrust actions against the professions have been opened, future lawsuits will probably soon begin testing these standards and procedures on a regular basis. The message to the professions seems clear: it is time to assure that your house is in order.

\section{The Substantive Standard. ${ }^{186}$}

In general it seems likely, even though there is no direct case law on point, that self-regulation by the professions will be tested by the usual antitrust rules where such self-regulation is not exempt from the Sherman Act because of the state action exemption. This means that price fixing or equivalent conduct (including fee advertising bans), allocation of clients, some forms of group boycotts and perhaps tying arrangements will be subject to per se rules. That is, when a medical society's regulation of physician practices fits within one of these categories, antitrust liability will be established upon a showing that the society engaged in these activities and, in some situations, that a substantial volume of business was involved or that the society had the economic power to implement its program. Under most of these circumstances it will not be necessary to show the actual competitive impact of the practice, nor will an antitrust court hear, much less accept, organized medicine's justifications for the restraint. ${ }^{187}$

But it is outside these egregious categories where most of the challenges are likely to occur-especially if physicians take the precautionary steps of retaining effective counsel and curtailing obviously anticompetitive practices. And it is here that the rule of reason will be

183. Id. at $364-65$.

184. See text accompanying notes 186-205 infra.

185. See text accompanying notes 180-83 supra.

186. See generally Note, Sherman Act Scrutiny of Bar Restraints on Advertising and Soliciation by Attorneys, 62 VA. L. REv. 1135 (1976).

187. See National Soc'y of Professional Eng'rs v. United States, 98 S.Ct. 1355 (1978) (ethical canon prohibiting engineers from submitting competitive bids violates $\S 1$ of the Sherman Act "on its face"). 
the antitrust standard. Under the rule of reason approach, the courts examine the purpose, power and market place effect of the parties' collaboration and also consider whether reliance should have been placed upon less restrictive alternatives to achieve similar ends. ${ }^{188}$

There are indications in some recent Supreme Court opinions that the courts will tread lightly in applying otherwise rigorous antitrust standards to physician self-regulation. In Virginia State Board of Pharmacy, ${ }^{189}$ the Court took care to state that pharmacists were different from physicians and lawyers: "Physicians and lawyers, for example, do not dispense standardized products; they render professional services of almost infinite variety and nature, with the consequent enhanced possibility for confusion and deception if they were to undertake certain kinds of advertising." 190 A year later, in Bates, the Court condemned a total ban of all price advertising when applied against an advertisement for five standardized legal services. But it reached this result only after a careful rule of reason analysis, albeit under the first amendment, even though under traditional antitrust analysis the prohibition was clearly illegal. In both cases the Court made clear that "[a]dvertising [by lawyers] that is false, deceptive, or misleading of course is subject to restraint." 191

However, the clearest guide suggesting that the professions operate under a more relaxed antitrust standard was announced in footnote 17 of the Court's opinion in Goldfarb:

The fact that a restraint operates upon a profession as distinguished from a business is, of course, relevant in determining whether that particular restraint violates the Sherman Act. It would be unrealistic to view the practice of professions as interchangeable with other business activities, and automatically to apply to the professions antitrust concepts which originated in other areas. The public service aspect, and other features of the professions, may require that a particular practice, which would properly be viewed as a violation of the Sherman Act in another context, be treated differently . . . . ${ }^{192}$

The Court has given no intimation beyond the minimum fee schedule tested in Goldfarb as to which situations will be treated more lightly. In National Society of Professional Engineers v. United States ${ }^{193}$ the Court

188. For a general discussion of the rule of reason standard, see E. Gellhorn, ANTITRUST LAW AND ECONOMICS 219-24 (1976); L. SulLIVAN, HANDBOoK OF THE LAw OF ANTITRUST 17182, 187-92 (1977).

189. See note 6 supra and text accompanying notes 5-9 supra.

190. 425 U.S. at 773 n.25 (emphasis supplied).

191. Bates, 433 U.S. at 383; accord, Virginia State Bd. of Pharmacy, 425 U.S. at 771-72 \& n.24.

192. 421 U.S. at 788 n.17.

193. 98 S.Ct 1355 (1978). 
ruled that the suppression of competitive bidding was illegal "on its face."

The question for physician advertising, then, is whether the Court would view suppression as a per se violation or whether deference to self-regulation would result in a rule of reason approach. The Court would most likely treat suppression of price advertising as a per se violation, in line with nonmedical precedent, but would leave other advertising restraint to a rule of reason. Cases examining concerted refusals to deal or group boycotts are instructive. Although courts and commentators occasionally point to particular Supreme Court decisions justifying a per se rule applicable to group boycotts, these cases usually can be distinguished, with the result that a varying standard is applied. ${ }^{194}$ In $A M A$ v. United States, ${ }^{195}$ a local medical society had warned hospitals that they might lose its approval if they allowed two former members expelled from the society to use their facilities; the physicians had participated in a prohibited group prepaid medical practice. The society had ruled that salaried medical practice was unprofessional conduct because it put an intermediary between the physician and the patient. ${ }^{196}$ The Court analyzed the practice differently. It condemned the society's actions as a secondary boycott of the hospitals-a per se violation-because the "unethical" conduct appeared to affect physician income much more than patient care. ${ }^{197}$

On the other hand, where the rational relationship between the professional rule and public protection is much closer, courts appear more willing to uphold self-regulation even if enforced by a group boycott. ${ }^{198}$ Ethical rules, for example, may be primarily designed to insure the integrity of the enterprise and to protect public interests. This is the basis upon which disciplinary rules of professional sports

194. See United States v. National Soc'y of Professional Eng'rs, 555 F.2d 978, 982-83 (D.C. Cir. 1977), affd, 98 S. Ct. 1355 (1978); Surety Title Ins. Agency v. Virginia State Bar, 431 F. Supp. 298, 304 n.8 (E.D. Va. 1977).

195. 317 U.S. 519 (1943).

196. United States v. AMA, 110 F.2d 703, 706-07 (D.C. Cir. 1940).

197. 317 U.S. at 535-36.

198. Judge Sneed has summarized the legal standard in Boddicker v. Arizona State Dental Ass'n, 549 F.2d 626 (9th Cir.), cert. denied, 434 U.S. 825 (1977). A particular practice, rule or regulation of a profession will withstand antitrust challenge only if

[it] serve[s] the purpose for which the profession exists, viz. to serve the public. That is, it must contribute directly to improving service to the public. Those which only suppress competition between practitioners will fail to survive the challenge.

$549 \mathrm{~F} .2 \mathrm{~d}$ at 632 . This statement may be too lenient on the professions, however, if read as upholding rules which have both desirable as well as undesirable purposes or which also have a substantial anticompetitive impact. Cf. E. GellHorN, supra note 188, at 203-04 (1976). Indeed, Judge Sneed explicitly recognized that his statement of the legal standard was only a principle rather than a "blueprint . . . which will resolve all controversies." 549 F.2d at 632. 
leagues-such as those against fighting or gambling-are upheld. In United States v. Oregon State Medical Society, ${ }^{199}$ the Supreme Court in dictum observed that

there are ethical considerations where the historic direct relationship between patient and physician is involved which are quite different than the usual considerations prevailing in ordinary commercial matters. This Court has recognized that forms of competition usual in the business world may be demoralizing to the ethical standards of a profession. ${ }^{200}$

Whether this statement of a quarter century ago would be followed today is uncertain. True, the careful analysis of price advertising prohibitions by the Bates Court may suggest that medicine and law have a special place. Yet if one looks to the results, where such restraints have been invariably condemned after this hand-wringing analysis, one wonders whether only a more circuitous route has been added.

The particulars of the AMA's no-solicitation rule prohibiting all advertising except basic name, office location and type of practice information is currently under challenge by the FTC. ${ }^{201}$ The AMA's trial brief argues that these restrictions are necessary to avoid consumer deception, retain patient trust and confidence, and protect service quality; ${ }^{202}$ the restrictions also comport with state and federal laws. ${ }^{203}$ In light of the Supreme Court's analysis and dismissal of similar arguments in Bates -admittedly, a first amendment case where only price advertising for five standard services was at stake-it seems likely that if a decision on the merits is reached, ${ }^{204}$ the AMA position will not succeed.

If a rule of reason analysis is applied, the more difficult questions (apparently not being addressed in the FTC's action against the AMA) are what effect, if any, third-party payment practices, the widespread

199. 343 U.S. 326 (1952).

200. Id. at 336 (dictum).

201. See AMA, FTC Dkt. No. 9064, [1973-76 Transfer Binder] Trade REG. ReP. (CCH) I 21,068 (1975).

202. Brief for Respondent at 53-66, AMA, FTC Dkt. No. 9064, [1973-76 Transfer Binder] TRADE REg. Rep. (CCH) I 21,068 (1975).

203. Id. 67-73.

204. There may be some doubt, however, as to whether the FTC has jurisdiction over the AMA. The FTC Act limits the Commission's jurisdiction to entities "organized to carry on business for its own profit or that of its members." 15 U.S.C. $\S 44$ (1976). See Community Blood Bank of Kansas City Area, Inc. v. FTC, 405 F.2d 1011, 1022 (8th Cir. 1969) (FTC without jurisdiction over nonprofit entity conducted for charitable purposes). The question is whether jurisdiction can, in this case, be established by showing that the AMA operates for the profit of its members. See generally FTC v. Cement Institute, 333 U.S. 683 (1948); FTC v. National Comm'n on Egg Nutrition, 517 F.2d 485 (7th Cir. 1975), cert. denied, 426 U.S. 919 (1976). 
availability of insurance and the role of the physician in making consumer choices for the patient should have on the no-advertising rules of the AMA and local medical societies. If demand is highly inelastic, wide-open advertising rules could simply result in higher prices. Alternatively, the number of consumers without insurance or uninformed of available low fee services may be so large that advertising could have a significant effect upon the delivery of medical services. Structurally, the physician services market is highly individualistic and highly fragmented, with most practices limited to solo practitioners or two-person offices. ${ }^{205}$ This might suggest that the market for physician services is already sufficiently competitive and that advertising would add little. If so, current prohibitions may be more acceptable. On the other hand, specialization and strict licensure restraints point in the other direction. As this line of questioning suggests, whether current or modified advertising restraints will pass antitrust scrutiny ultimately should depend upon a factual analysis not possible with the information available today. If it is necessary to speculate, however, it seems doubtful that a total ban would survive a rule of reason analysis.

\section{CONCLUSION}

The range of self-regulation permitted the professions is currently undergoing reexamination. In light of past restrictive practices that prevented virtually all professional advertising under the guise of protecting the public-even though the restraint also clearly protected monopoly interests and prevented effective competition-this reconsideration is overdue. On the other hand, the courts have moved cautiously and there seems to be no reason for undue alarm in the professions. Change will come, and it may be disruptive to some; it should not, however, adversely affect the quality and scope of services made available to the public.

This reevaluation of past rulings which took a hands-off attitude toward the professions presents an opportunity for courts and commentators to rethink old doctrines. This has already occurred with the recent extension of the first amendment to commercial speech. The purpose, of course, is to place more information in the hands of consumers. This is an appropriate task for the first amendment because in the economy, as in politics, knowledge is power. A basic shift in power to the consumer is itself a change in the political balance. The ultimate responsibility for health decisions affecting the consumer lies with the consumer; he or she makes the immensely important initial decisions

205. A. NICHOLS, supra note 26 , at $33-34$. 
whether to let a complaint go untreated, whether to administer selftreatment or whether to employ a physician and, if so, which one to select. If these choices are to be free, they should be informed. In all probability, the state has a moral duty to encourage the flow of information to the general public. It certainly ought not to aid the medical profession in stemming the flow. The Supreme Court's injection of the first amendment into professional advertising rightly precludes the state from taking such a negative role. And if the Bates decision is correctly applied, it will create a presumption in each case in favor of disclosure and will require strong justification for restraints on truthful advertising.

The first amendment is a specialized tool, however, and a somewhat inflexible one. There are many restrictive practices of the professions that may adversely affect the consumer and that the first amendment cannot reach because they do not involve the suppression of information. Even in the regulation of advertising, there is likely to be resistance to subjecting every detail of regulation to a constitutional mandate. If such rulings are placed on first amendment grounds, they cannot be overturned by legislation. This is not to say that the first amendment must not inform decisions concerning the regulation of professional advertising; in the case of attorneys, at least where regulatory rules are written and enforced by state supreme courts, the first amendment is the only effective control on professional self-interest. But to achieve a fine-tuned policy governing professional regulation that is responsive to economic nuances, the first amendment is hardly the ideal instrument.

On the other hand, just the opposite may be said of the Sherman Act. Its application is appropriate to test the entire range of self-regulation by the professions. Despite declarations of public service and of a desire to protect the public from misguided efforts at competition, most professional ethical standards appear to be guided more by monopolistic self-interest than by anything else-the kind of self-interest that the Sherman Act was designed to control. This fact, furthermore, ought to justify a presumption against validity when these restrictive practices are measured against the Sherman Act. This point is urged because it would involve a reversal of the current judicial approach which deals so circumspectly with and with such deference to almost every argument urged by lawyers or physicians in favor of restrictive ethical requirements. Since many, and perhaps most, of these arguments are at best well-phrased covers for anticompetitive arrangements with little other justification, they should be considered as such when measured against the legislative standard favoring competition and its benefits. 
This further suggests that the exemptions from Sherman Act jurisdiction which are still relied upon to protect professional canons from antitrust scrutiny should be reconsidered and applied narrowly. The state action defense seems to be a prime candidate for reexamination. Its main thrust was to protect state sovereignty and to assure that substantive due process did not reappear in new dress. Neither justification seems persuasive today. ${ }^{206}$ If we are to have a national antitrust policy, state sovereignty must give way to federal supremacy, at least in professional self-regulation. The state action doctrine allows state government in this instance to create exceptions to the Sherman Act which swallow up its rule in whole sectors of the economy. Now that we have begun to appreciate the importance of the professions to the economy, especially with the increasing role of the service sector in all phases of society, the real benefits of competition should not be lost. Studies of occupational licensure and similar state regulatory schemes have repeatedly shown their detrimental impact upon the economy. ${ }^{207}$ If the Parker doctrine is allowed to stand in its current form and be reinforced by citation and reliance, the gains made during the past few years in curbing the monopolistic tendencies of the professions will be frustrated and the public ill served.

There is no reason to fear that elimination, or at least narrowing, of the state action defense would foster the rebirth of substantive due process and the substitution of the economic ideologies of judges for

206. Specifically, we find the arguments offered by Professors Handler and Verkuil, supra note 132, and especially their fears of a narrowed state action rule, unjustified. They rely primarily upon concerns that many state regulatory programs would be overridden, regulated firms would be unfairly subjected to treble damage liability (which was also a concern of the Supreme Court in oral argument in Bates) and the people's will, as expressed in state legislation, would be subject to being overruled by capricious federal judges. On the other hand, state regulations inconsistent with other federal laws (e.g., federal labor laws) are generally held to minimum standards of consistency. See Bartosic, The Supreme Court, 1974 Term: The Allocation of Power in Deciding Labor Law Policy, 62 VA. L. REv. 533 (1976). Applied to state economic regulation, the "state action" doctrine should exempt only state regulatory programs that assure the benefits of competition and involve active state enforcement. Thus, public utility regulation of natural monopolies (e.g., telephone rates, water and sewer systems) would survive as would most, but not all, state regulation. The problem of fairness apparently could be resolved in the same manner that criminal enforcement is handled under the Sherman Act, despite its vagueness; that is, new extensions of the Sherman Act should be developed in declaratory judgment or equitable actions for injunctions. Private treble damages should not be available retrospectively as the result of such extensions. Cf. Linkletter v. Walker, 381 U.S. 618 (1965) (prospective overruling in constitutional litigation). Finally, there seems to be no reason either to pay greater heed to state legislative judgments (as compared to those made by Congress) here than in other contexts or to accept the conjecture that federal judges will ignore the substantial gloss on the Sherman Act in applying it where private or quasi-public conduct is for the first time undergoing federal antitrust challenge. The federal judiciary has not been particularly active in extending antitrust liability.

207. B. Shimberg, B. Esser, \& D. Druger, Occupational licensing: Practices and PoLICIES (1972); Gellhorn, The Abuse of Occupational Licensing, 44 U. CHI. L. Rev. 6 (1976). 
those of the legislatures. This is because the exemption's removal would not be a license to judges to insert their own views; the Sherman Act would still be applied and it has a well-defined scope and rationale. Nor would state regulation be overturned in every respect. Rather, the effect would be that state regulation could not be relied upon to avoid antitrust liability for collaborative action. To the extent that the professions do not engage in otherwise illegal joint action, or that interstate commerce is unaffected, the state regulation would continue. In light of the liberal interpretation given professional standards under the rule of reason-even if reinterpreted to place on the profession the burden of justifying the restrictive practice-the standards would be upheld where the likely or realized benefits outweighed the costs or risks. Moreover, any possible judicial introduction of personal value judgments could be closely monitored by Congress since the courts would be interpreting a legislative command (the Sherman Act) rather than the Constitution, as was the case with substantive due process. Recent congressional revisions of the antitrust laws indicate that legislative control of judicial pronouncements is not as difficult as it once appeared.

The Court has taken an important step in opening the professions to competition. The strong bias the Court has exhibited for freedom to speak and compete should be strengthened and encouraged. Continuing restraints developed by the professions or their regulatory agencies should be approved only if narrowly drawn to meet particular needs and after solid justifications have been established. Loosely drawn prohibitions covering desirable as well as undesirable actions should be avoided. Perhaps then the professions' performance will more nearly match their promise. 
- 